\title{
RELATIONSHIP BETWEEN RNASE1, ANG AND RNASE6 GENE POLYMORPHISM AND THE VALUES OF BLOOD INDICES IN SUCKLING PIGLETS
}

\author{
Hanna SZYMAŃSKA $^{1 *}$, Krystyna ŻYCZKO ${ }^{2}$ and Tadeusz ZABOLEWICZ ${ }^{2}$ \\ ${ }^{1}$ Department of Medical Biology, University of Warmia and Mazury, Żołnierska 14C, \\ 10-561 Olsztyn, Poland; ${ }^{2}$ Department of Animal Genetics, University of Warmia and \\ Mazury, Olsztyn, Poland
}

(Received 6 July 2018; accepted 2 May 2019)

\begin{abstract}
The relationship between PCR-restriction fragment length polymorphism in RNASE1 (296 A/G), ANG (149 G/T) and RNASE6 (389 C/T) genes and the values of haematological and biochemical blood indices was analysed in crossbred suckling piglets $(\mathrm{n}=473)$, aged $21 \pm 3$ days (younger, $\mathrm{n}=274)$ and $35 \pm$ 3 days (older, $n=199$ ), descending from Polish Large White $\times$ Polish Landrace sows and Duroc $\times$ Pietrain boars. The observed distribution of all genotypes was consistent with the Hardy-Weinberg equilibrium. Anaemia was more common in younger piglets with RNASE1 GA genotype but in the blood of older GA piglets a higher count and percentage of granulocytes were noted. This could be related to the destruction of erythrocytes in younger piglets and enhanced host defence in older ones. $A N G$ gene polymorphism was associated with the severity of iron deficiency in younger piglets. This is supposed to be linked with the different ability to protect immune cells against suppression and degradation during iron deficiency. In older piglets, this mutation differentiated the reactivity of the immune system. Varying levels of iron status and red blood cell indices in RNASE6 genotypes presumably resulted from the coupling of genes involved in iron metabolism and expressed in an age-dependent manner.
\end{abstract} piglets

Key words: $R N A S E 1, A N G, R N A S E 6$, gene polymorphism, blood indices,

RNASE1, ANG and RNASE6 genes encoding ribonuclease 1 (RNase 1), angiogenin (RNase 5) and RNase $6(\mathrm{k} 6)$ are homologues of the bovine pancreatic RNase A, involved in RNA hydrolysis (Koczera et al., 2016). Based on the National Center for Biotechnology Information (NCBI) database, these genes are located on porcine chromosome 7 while RNASE1 gene lies in the region homologous to the human chromosome $14 \mathrm{q} 11.2-13$, in which there are genes important for immunological processes (Tammen et al., 1999).

\footnotetext{
*Corresponding author; E-mail: hanna.szymanska@uwm.edu.pl;
} Phone: 0048 (89) 524-6124; Fax: 0048 (89) 524-6116 
Pancreatic RNase 1 as a digestive enzyme on food-derived RNA was suggested to participate in the immune response due to its expression in immune cells (Koczera et al., 2016). Moreover, acute inflammation induced by extracellular RNA caused the immediate release of endothelial RNase 1, while chronic, cytokine-mediated inflammation inhibited its expression (Gansler et al., 2013). Angiogenin as a stimulator of angiogenesis activates the endothelium through signalling pathways or direct translocation to the nucleus where it promotes rRNA transcription, ribosome biogenesis, protein translation and cell proliferation. Protein cytotoxicity emerges from the hydrolysis of tRNA (Sheng and $\mathrm{Xu}, 2016$ ). The cytoprotective role of angiogenin includes the generation of tRNA-derived stress induced RNAs (tiRNA), the formation of cytoplasmic stress granules, the inhibition of protein synthesis, and stimulation of the expression of anti-apoptotic genes (Pizzo et al., 2013). Angiogenin secretion is also regulated as a positive acute phase protein in humans and mice (Sheng and $\mathrm{Xu}, 2016$ ). The RNASE6 gene has been found to participate in immune processes due to its expression in monocytes and neutrophils but not in eosinophils (Pulido et al., 2016). Recently, RNase 6 has been recognised as a conserved and antibacterial protein (Pulido et al., 2016).

Data on pig RNase genes are limited to the publication of Bai et al. (2009), which presented their coding sequences: RNASE1 (GenBank: EU814500), ANG (GenBank: EU814501) and RNASE6 (GenBank: EU814502) and single nucleotide polymorphisms (SNPs) within them: $296 \mathrm{~A} / \mathrm{G}, 149 \mathrm{G} / \mathrm{T}$ and $389 \mathrm{C} / \mathrm{T}$. Based on the link between the RNase gene mutations and the level of selected blood cell indices in newborn piglets, the authors proposed to consider them as candidate genes for innate immunity in pigs.

The aim of this study was to verify the relationship between the polymorphism of RNASE1, ANG and RNASE6 genes and the values of selected biochemical and haematological indices in suckling piglets, taking into account their age and health status.

\section{Materials and methods}

\section{Animals}

The experimental animals comprised crossbred suckling piglets $(n=473)$ without clinical signs of disease, kept in a private farm and descending from Polish Large White $\times$ Polish Landrace sows and Duroc $\times$ Pietrain boars. They were divided into two groups: younger $(n=274)$ and older $(n=199)$, aged $21 \pm$ 3 and $35 \pm 3$ days, respectively. In the first week of their life, piglets received Suibiofer SE (Biowet, Drwalew SA), they had their tails docked and teeth clipped, and the boars were castrated. From the second week of life, additional feed intake was provided. With the approval of the Local Animal Ethics Committee (No. 9/2008N), blood was sampled from the jugular vein for molecular, haematological and biochemical analyses. 


\section{Molecular analysis}

DNA was isolated from whole blood using the MasterPure ${ }^{\mathrm{TM}}$ Genomic DNA Purification Kit (Epicentre, USA) and the quantitative and qualitative assessment was performed using GeneQuant spectrophotometer (Pharmacia LKB Biochrom Ltd, UK). SNPs in RNASE1 (296 A/G, GenBank: EU814500), ANG (149 G/T, GenBank: EU814501) and RNASE6 (389 C/T, GenBank: EU814502) genes were identified by the PCR-restriction fragment length polymorphism (PCRRFLP) method with restriction enzymes MboI, ApaI and MspI (Fermentas), respectively, according to Bai et al. (2009), with a modification developed at the Department of Animal Genetics. PCR amplifications of all genes were based on the same $25-\mu \mathrm{L}$ reaction mixture, containing PCR buffer $(20 \times), 25 \mathrm{mM} \mathrm{MgCl}_{2}, \mathrm{PCR}$ Enhancer $(10 \times), 2.5 \mathrm{mM}$ dNTPs, $50 \mathrm{pM}$ of each primer, 1U Tfl DNA polymerase (Epicentre, USA), $100 \mathrm{ng}$ of genomic DNA, and deionised, autoclaved water. PCRs were performed using Thermal Cycler PTC-200 (Bio-Rad, USA). For amplification of RNASE1 and RNASE6 genes touchdown PCR programs were used: $2 \mathrm{~min}$ at $94{ }^{\circ} \mathrm{C}$, followed by 30 cycles of $30 \mathrm{~s}$ at $94^{\circ} \mathrm{C}, 30 \mathrm{~s}$ at annealing temperatures: from $65^{\circ} \mathrm{C}$ to $64{ }^{\circ} \mathrm{C}\left(-1{ }^{\circ} \mathrm{C} / 1\right.$ cycle $), 63{ }^{\circ} \mathrm{C}-60{ }^{\circ} \mathrm{C}\left(-1{ }^{\circ} \mathrm{C} / 2\right.$ cycles $)$, $58{ }^{\circ} \mathrm{C}-56{ }^{\circ} \mathrm{C}\left(-2{ }^{\circ} \mathrm{C} / 5\right.$ cycles $)$ and 10 cycles at $54^{\circ} \mathrm{C}, 30 \mathrm{~s}$ at $72{ }^{\circ} \mathrm{C}$ and a final extension of $5 \mathrm{~min}$ at $72^{\circ} \mathrm{C}$. The PCR conditions for the $A N G$ gene were $5 \mathrm{~min}$ at $94{ }^{\circ} \mathrm{C}$, followed by 35 cycles of $30 \mathrm{~s}$ at $94{ }^{\circ} \mathrm{C}, 30 \mathrm{~s}$ at $60^{\circ} \mathrm{C}, 30 \mathrm{~s}$ at $72{ }^{\circ} \mathrm{C}$ and a final extension of 5 min at $72{ }^{\circ} \mathrm{C}$. An $8-\mu \mathrm{L}$ aliquot of each PCR product was digested with the particular restriction enzymes $\left(1 \mathrm{U} \mu \mathrm{L}^{-1}\right)$ at $37^{\circ} \mathrm{C}$ for $10-15 \mathrm{~min}$. Restriction fragments were electrophoresed in $2.5 \%$ agarose gels stained with ethidium bromide and visualised using the Fluor-S MultiImager (Bio-Rad, USA).

\section{Haematological and biochemical analyses}

The following haematological indices were determined in a veterinary laboratory: leukocyte count (WBC), lymphocyte count (LYM) and percentage (\%LYM), granulocyte count (GRA) and percentage (\%GRA), monocyte count (MONO) and percentage (\%MONO), erythrocyte count (RBC), haemoglobin concentration (HGB), mean corpuscular volume (MCV), haematocrit (HCT), mean corpuscular haemoglobin $(\mathrm{MCH})$, mean corpuscular haemoglobin concentration (MCHC), red cell distribution width (RDW), thrombocyte count (PLT), mean platelet volume (MPV), platelet distribution width (PDW), and percentage of large platelets (LPLT), using an automated blood analyzer NS4 (Cedex). The biochemical parameters included the levels of high-density lipoprotein cholesterol (HDL-ch), iron (Fe) (BioSystems SA, Spain) and total iron binding capacity (TIBC) (SPINREACT SA, Spain), which were determined according to the manufacturer's procedure. Transferrin saturation (\%Tf) was calculated as the ratio of serum iron concentration and TIBC expressed in percentages. On the basis of the values of blood indices younger piglets $(n=221)$ were subdivided into 
three groups: healthy piglets $[\mathrm{n}=133$, values of blood indices within the reference ranges according to Egeli et al. (1998)], anaemic piglets $[n=60$, haemoglobin level below $8 \mathrm{~g} / \mathrm{dL}$ and blood values typical of anaemia (Egeli et al., 1998)] and piglets deviating from the physiological norm $(\mathrm{n}=28$, WBC count below and above 11-22 $\times 10^{9} / \mathrm{L}$ and the number and percentage of leukocyte subpopulations also outside the reference range) (Duncan and Prasse, 1986; Egeli et al., 1998; Quintero-Gutiérrez et al., 2008). The discrepancy between the number of genotyped and haematologically and biochemically examined piglets (younger, $\mathrm{n}=274$ and $\mathrm{n}=221$; older, $\mathrm{n}=199$ and $\mathrm{n}=181$ ) was due to the haemolysis of some blood samples from younger $(\mathrm{n}=53)$ and older $(\mathrm{n}=18)$ piglets.

\section{Statistical analysis}

The population genetic structure was analysed by determining allele and genotype frequencies at loci of particular genes. Contingency table analysis with Chi-square test $\left(\chi^{2}\right)$ was applied to analyse the genetic equilibrium of the population and to determine the relationship between the genotype and the health status of piglets. The Lilliefors (Kolmogorov-Smirnov) test was used to check whether the distribution of trait values in the herd of piglets was normal. The lack of normal distribution prompted the use of non-parametric tests for further analysis. The Mann-Whitney test and the Kruskal-Wallis test with a post-hoc analysis were used to determine the significance of differences between the median values of two and three compared genotypes, respectively. All analysed properties were presented with the following descriptive statistics: median (Mdn), minimum (Min) and maximum (Max) values. The arithmetic mean $(\bar{x})$ and standard deviation (s) values were also given. Statistical analysis was performed using the STATISTICA 9.0 software package (StatSoft Inc., USA).

\section{Results}

The results of analysis of genetic population structure are presented in Table 1 . The observed distribution of all genotypes was consistent with the HardyWeinberg equilibrium.

Tables 2 and 3 display the variability of blood parameters analysed in younger and older piglets, respectively. The range of haematology and serum biochemistry values in younger piglets resulted made it necessary to divide into groups and to verify the relationship between the polymorphism of the studied genes and the health status of piglets. Only the SNP in the RNASE1 gene was associated with the number of anaemic piglets. The deficit of AA piglets and the excess of GA piglets were found (Table 4).

The values of blood parameters in piglets depending on their genotype are presented only as statistically significant differences in Tables 5,6 and 7. As a 
result of RNASE1 (296 A/G) gene polymorphism, younger AA piglets had higher WBC including LYM, MONO and GRA than GA piglets (Table 5). Homozygotes were also characterised by higher \%GRA and lower \%LYM and \%MONO. In the blood of AA piglets higher RBC, HGB and HCT but lower RDW and PDW values were noted. Healthy piglets with AA genotype were distinguished from GA piglets by higher WBC and GRA counts and percentages and lower \%LYM. Moreover, they had higher Fe and HCT as well as higher MCV and $\mathrm{MCH}$. At the same time, anaemic piglets were found to differ only with regard to $\mathrm{MCV}$ and $\mathrm{MCH}$ levels which were higher in GA individuals. In older piglets, in contrast to younger ones, piglets of GA genotype had higher WBC and GRA counts and percentages. The \%LYM and HDL-ch turned out to be lower than in the AA genotype. Among the RBC indices, an increased $\mathrm{MCH}$ in the blood of GA piglets was accompanied by a decreased RDW.

Table 1

Genetic structure of the studied population

\begin{tabular}{|c|c|c|c|c|c|c|c|c|}
\hline \multirow[t]{2}{*}{ Mutation } & \multirow[t]{2}{*}{ Genotypes } & \multicolumn{2}{|c|}{$\begin{array}{c}\text { Number } \\
\text { and frequency } \\
\text { of genotypes }\end{array}$} & \multirow{2}{*}{$\begin{array}{l}\text { Expected } \\
\text { number } \\
\text { of } \\
\text { genotypes }\end{array}$} & \multirow[t]{2}{*}{$\chi^{2}$ value } & \multirow[t]{2}{*}{$P$ value } & \multicolumn{2}{|c|}{ Allele frequency (\%) } \\
\hline & & $\mathrm{n}$ & $\%$ & & & & $R N A S E 1^{\mathrm{A}}$ & $R N A S E 1^{\mathrm{G}}$ \\
\hline \multirow{5}{*}{$296 \mathrm{~A} / \mathrm{G}$} & AA & 424 & 89.6 & 425.09 & 0.003 & & \multirow{4}{*}{94.8} & \multirow{4}{*}{5.2} \\
\hline & GA & 49 & 10.4 & 46.63 & 0.120 & & & \\
\hline & GG & 0 & 0 & 1.28 & 1.280 & & & \\
\hline & Together & 473 & 100 & 473 & 1.403 & 0.496 & & \\
\hline & & & & & & & $A N G^{\mathrm{G}}$ & $A N G^{\mathrm{T}}$ \\
\hline \multirow{5}{*}{$149 \mathrm{G} / \mathrm{T}$} & GG & 323 & 68.3 & 325.85 & 0.025 & & \multirow{4}{*}{83.0} & \multirow{4}{*}{17.0} \\
\hline & TG & 139 & 29.4 & 133.48 & 0.228 & & & \\
\hline & TT & 11 & 2.3 & 13.67 & 0.521 & & & \\
\hline & Together & 473 & 100 & 473 & 0.774 & 0.679 & & \\
\hline & & & & & & & $R N A S E \sigma^{\mathrm{C}}$ & $R_{N A S E \sigma^{\mathrm{T}}}$ \\
\hline \multirow{4}{*}{$389 \mathrm{C} / \mathrm{T}$} & $\mathrm{CC}$ & 119 & 25.2 & 119.67 & 0.004 & & \multirow{4}{*}{50.3} & \multirow{4}{*}{49.7} \\
\hline & $\mathrm{TC}$ & 238 & 50.3 & 236.49 & 0.010 & & & \\
\hline & TT & 116 & 24.5 & 116.84 & 0.006 & & & \\
\hline & Together & 473 & 100 & 473 & 0.020 & 0.990 & & \\
\hline
\end{tabular}

$\chi^{2}=$ chi-square value; df $2: \chi^{2}{ }_{.05}=5.991-$ the tabular $\chi^{2}$ value at 2 degrees of freedom (df) and a probability $(\mathrm{P})$ of 0.05

As a result of $A N G(149 \mathrm{G} / \mathrm{T})$ gene polymorphism a significant difference in MCH level was found in younger piglets (Table 6), which was higher in GG piglets than in heterozygotes. In turn, in healthy younger GG piglets $\mathrm{Fe}$ and \% $\mathrm{Tf}$ were higher than in TG. Likewise, higher serum Fe and \% Tf were demonstrated 
in GG piglets deviating from the physiological norm. This genotype was also marked by a higher MCV and $\mathrm{MCH}$ compared to heterozygotes. Among the younger piglets only the anaemic animals showed significant differences in WBC including MONO and GRA, which were higher in the blood of GG animals compared to TG piglets. Furthermore, in the blood serum of homozygotes a decreased \% Tf and an increased RDW were found. In the blood of older GG piglets a significantly lower WBC count was noted than in heterozygotes and opposite homozygotes, which were similar in this respect. This was caused by the lower GRA and LYM of GG piglets compared to the other genotypes. GG homozygotes were also characterised by the highest $\mathrm{MCH}$ as well as MCHC compared to heterozygotes and opposite homozygotes. Heterozygotes and TT homozygotes did not differ in the values of these parameters. Besides, older GG piglets had higher MPV than TT individuals, and a greater PDW than the other genotypes.

Table 2

The levels of haematological and biochemical indices in younger piglets

\begin{tabular}{|c|c|c|c|c|c|}
\hline Indices & $\mathrm{n}$ & Mdn & Min-Max & $\bar{x}$ & $\mathrm{~s}$ \\
\hline HDL-ch (mg/dL) & 274 & 61.00 & $29.00-112.00$ & 62.16 & 14.718 \\
\hline TIBC $(\mu \mathrm{mol} / \mathrm{L})$ & 274 & 124.47 & $50.33-216.35$ & 126.30 & 31.518 \\
\hline $\mathrm{Fe}(\mu \mathrm{mol} / \mathrm{L})$ & 274 & 10.93 & $2.69-51.22$ & 13.27 & 7.862 \\
\hline$\% \operatorname{Tf}(\%)$ & 274 & 9.01 & $1.32-40.74$ & 11.37 & 7.316 \\
\hline $\mathrm{WBC}\left(10^{9} / \mathrm{L}\right)$ & 221 & 14.80 & $1.67-35.89$ & 15.37 & 5.407 \\
\hline LYM $\left(10^{9} / \mathrm{L}\right)$ & 221 & 6.80 & $0.90-19.10$ & 7.06 & 2.609 \\
\hline$\%$ LYM $(\%)$ & 221 & 46.73 & $25.51-64.68$ & 46.80 & 8.852 \\
\hline MONO $\left(10^{9} / \mathrm{L}\right)$ & 221 & 1.50 & $0.30-4.50$ & 1.57 & 0.646 \\
\hline$\%$ MONO (\%) & 221 & 9.31 & $6.22-17.96$ & 10.37 & 2.832 \\
\hline $\operatorname{GRA}\left(10^{9} / \mathrm{L}\right)$ & 221 & 6.10 & $0.50-15.70$ & 6.75 & 3.138 \\
\hline$\%$ GRA $(\%)$ & 221 & 41.94 & $22.39-67.88$ & 42.90 & 9.652 \\
\hline $\operatorname{RBC}\left(10^{12} / \mathrm{L}\right)$ & 221 & 5.63 & $2.25-7.64$ & 5.47 & 1.051 \\
\hline $\operatorname{HGB}(\mathrm{g} / \mathrm{dL})$ & 221 & 9.40 & $3.90-15.20$ & 9.36 & 1.856 \\
\hline MCV (fL) & 221 & 50.10 & $38.90-64.60$ & 50.80 & 5.518 \\
\hline HCT (\%) & 221 & 27.40 & $12.50-43.30$ & 27.60 & 5.622 \\
\hline $\mathrm{MCH}(\mathrm{pg})$ & 221 & 17.10 & $13.60-21.80$ & 17.11 & 1.534 \\
\hline $\operatorname{MCHC}(\mathrm{g} / \mathrm{dL})$ & 221 & 34.00 & $28.20-42.70$ & 33.99 & 2.501 \\
\hline RDW (\%) & 221 & 17.50 & $11.10-27.80$ & 17.93 & 3.280 \\
\hline $\operatorname{PLT}\left(10^{9} / \mathrm{L}\right)$ & 221 & 955.00 & $55.00-2286.00$ & 989.04 & 396.51 \\
\hline MPV (fL) & 221 & 11.10 & $9.70-12.40$ & 11.08 & 0.516 \\
\hline LPLT $(\%)$ & 221 & 1.06 & $0.06-2.40$ & 1.09 & 0.416 \\
\hline PDW (\%) & 221 & 7.70 & $5.50-12.20$ & 7.76 & 1.024 \\
\hline
\end{tabular}

Mdn: median; Min-Max: minimum and maximum value; $\bar{x}$ : mean; s: standard deviation

As shown in Table 7, RNASE6 (389 C/T) gene polymorphism resulted in a variation in the level of biochemical, RBC and platelet indices only in the blood of younger piglets. Considerably higher TIBC and slightly lower \%Tf were ob- 
served in TT piglets than in CC animals. In TT piglets, TIBC was also higher than in heterozygotes, while \%Tf was lower. Increased MCV was noted in the blood of CC homozygotes and heterozygotes compared to TT piglets. In turn, $\mathrm{MCH}$ was of intermediate value in heterozygotes and did not differ significantly from that determined in both homozygotes. TT homozygotes were characterised by a lower level of this parameter than CC homozygotes. Piglets with TT genotype had higher PLT compared to TC and CC, which were different in this respect. LPLT was also increased in the blood of TT piglets compared to CC individuals. The LPLT of CC piglets was lower than that observed in heterozygotes, in which it was of intermediate value, close to the value found in TT homozygotes. However, in piglets which deviated from physiological norm, higher TIBC and lower \% Tf, together with a lower Fe, were measured in piglets of the TT genotype than in heterozygotes, while $\mathrm{CC}$ piglets were characterised by intermediate values of the above parameters and did not differ significantly from the other genotypes. Regarding the RBC indices, both $\mathrm{MCV}$ and $\mathrm{MCH}$ values turned out to be lower in the blood of TT piglets compared to TC and CC individuals.

Table 3

The levels of haematological and biochemical indices in older piglets

\begin{tabular}{|c|c|c|c|c|c|}
\hline Indices & $\mathrm{n}$ & Mdn & Min-Max & $\bar{x}$ & $\mathrm{~s}$ \\
\hline HDL-ch (mg/dL) & 199 & 49.00 & $20.00-83.00$ & 50.29 & 11.805 \\
\hline TIBC $(\mu \mathrm{mol} / \mathrm{L})$ & 199 & 90.98 & $20.42-150.26$ & 94.12 & 22.633 \\
\hline $\mathrm{Fe}(\mu \mathrm{mol} / \mathrm{L})$ & 199 & 21.76 & $6.63-37.79$ & 21.90 & 4.639 \\
\hline$\% \operatorname{Tf}(\%)$ & 199 & 24.31 & $6.42-59.20$ & 24.85 & 9.583 \\
\hline $\operatorname{WBC}\left(10^{9} / \mathrm{L}\right)$ & 181 & 20.19 & $8.44-39.03$ & 21.06 & 6.166 \\
\hline LYM $\left(10^{9} / \mathrm{L}\right)$ & 181 & 7.80 & $3.70-16.10$ & 8.08 & 2.323 \\
\hline$\%$ LYM (\%) & 181 & 38.50 & $16.36-57.89$ & 39.08 & 6.722 \\
\hline MONO $\left(10^{9} / \mathrm{L}\right)$ & 181 & 1.70 & $0.70-4.60$ & 1.91 & 0.694 \\
\hline$\%$ MONO (\%) & 181 & 8.44 & $5.17-16.67$ & 9.15 & 2.290 \\
\hline $\operatorname{GRA}\left(10^{9} / \mathrm{L}\right)$ & 181 & 10.90 & $4.10-24.30$ & 11.09 & 4.101 \\
\hline$\%$ GRA $(\%)$ & 181 & 52.10 & $32.21-77.71$ & 51.85 & 7.719 \\
\hline $\mathrm{RBC}\left(10^{12} / \mathrm{L}\right)$ & 181 & 6.52 & $4.85-7.89$ & 6.48 & 0.515 \\
\hline $\mathrm{HGB}(\mathrm{g} / \mathrm{dL})$ & 181 & 11.20 & $8.10-14.10$ & 11.19 & 1.072 \\
\hline MCV (fL) & 181 & 50.40 & $40.90-59.70$ & 50.27 & 4.122 \\
\hline $\operatorname{HCT}(\%)$ & 181 & 33.10 & $20.60-41.80$ & 32.54 & 3.910 \\
\hline $\mathrm{MCH}(\mathrm{pg})$ & 181 & 17.10 & $15.00-24.10$ & 17.24 & 1.171 \\
\hline $\mathrm{MCHC}(\mathrm{g} / \mathrm{dL})$ & 181 & 34.30 & $28.80-48.00$ & 34.52 & 2.278 \\
\hline RDW (\%) & 181 & 16.60 & $10.60-22.10$ & 16.20 & 2.733 \\
\hline $\operatorname{PLT}\left(10^{9} / \mathrm{L}\right)$ & 181 & 593.00 & $52.00-1744.00$ & 973.21 & 344.225 \\
\hline MPV (fL) & 181 & 10.90 & $9.50-13.30$ & 11.01 & 0.671 \\
\hline LPLT (\%) & 181 & 1.08 & $0.05-94.00$ & 1.58 & 6.917 \\
\hline PDW (\%) & 181 & 7.30 & $5.20-9.90$ & 7.52 & 1.036 \\
\hline
\end{tabular}

Mdn: median; Min-Max: minimum and maximum value; $\bar{x}$ : mean; s: standard deviation 


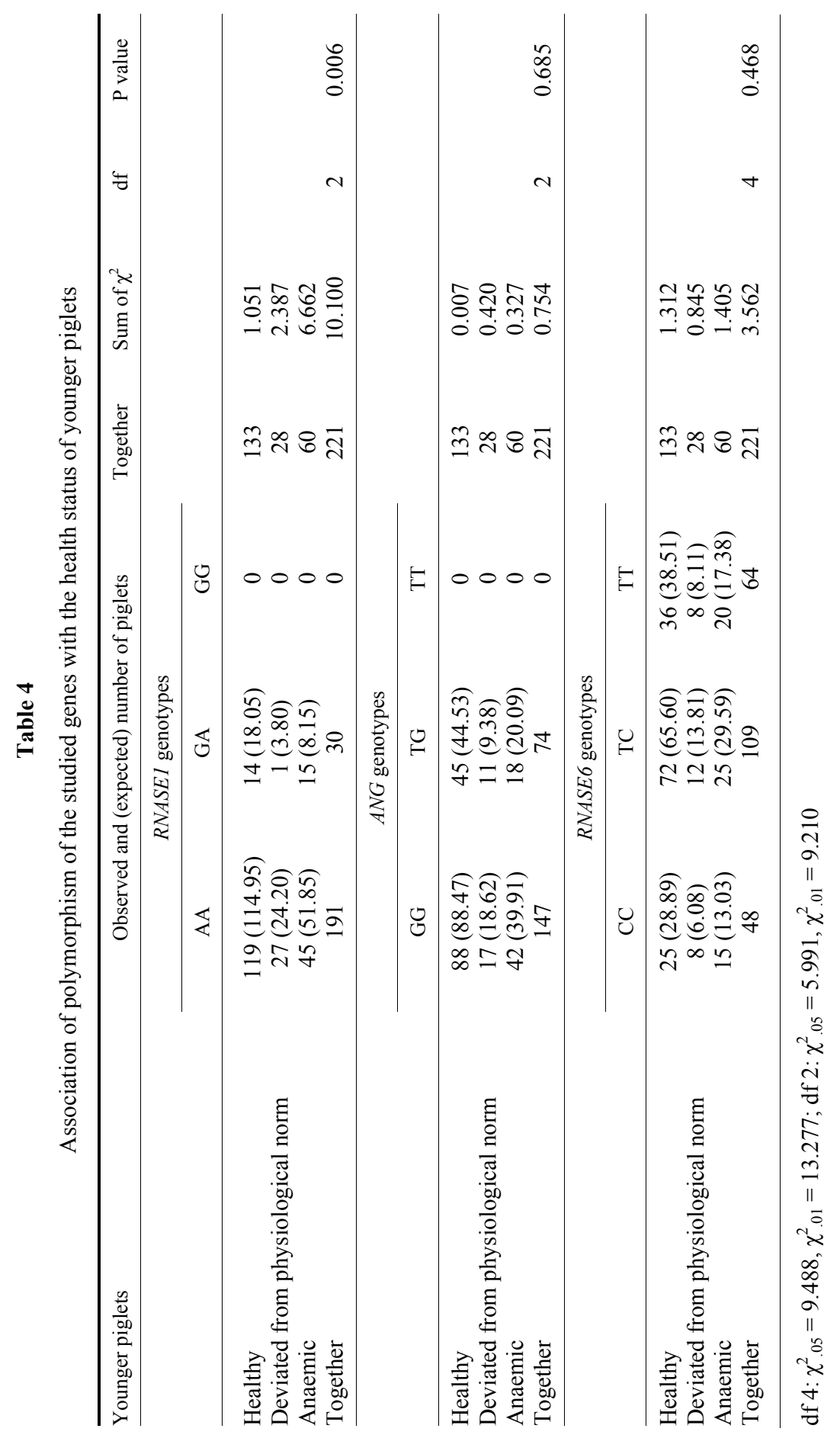


Table 5

The relationship between RNASE1 genotypes and the values of haematological and biochemical indices in suckling piglets

\begin{tabular}{|c|c|c|c|}
\hline \multirow{2}{*}{$\begin{array}{l}\text { Indices } \\
\text { Younger piglets }\end{array}$} & \multicolumn{2}{|c|}{ Mdn and (Min - Max) values of indices in piglets with genotypes: } & \multirow[t]{2}{*}{$\mathrm{P}$ value } \\
\hline & AA, $n=191$ & $\mathrm{GA}, \mathrm{n}=30$ & \\
\hline WBC $\left(10^{9} / \mathrm{L}\right)$ & $15.09(3.97-35.89)$ & $11.62(1.67-20.03)$ & $<0.001$ \\
\hline LYM $\left(10^{9} / \mathrm{L}\right)$ & $6.90(2.00-19.10)$ & $5.50(0.90-10.00)$ & 0.004 \\
\hline$\%$ LYM (\%) & $46.04(25.51-64.68)$ & $49.72(40.23-61.17)$ & 0.010 \\
\hline MONO $\left(10^{9} / \mathrm{L}\right)$ & $1.50(0.50-4.50)$ & $1.25(0.30-2.60)$ & 0.029 \\
\hline$\% \mathrm{MONO}(\%)$ & $9.19(6.22-17.63)$ & $12.47(7.05-17.96)$ & 0.003 \\
\hline GRA $\left(10^{9} / \mathrm{L}\right)$ & $6.40(1.30-15.70)$ & $4.55(0.50-8.70)$ & $<0.001$ \\
\hline$\%$ GRA, $\%$ & $42.60(22.39-67.88)$ & $37.61(27.81-52.93)$ & 0.002 \\
\hline $\mathrm{RBC}\left(10^{12} / \mathrm{L}\right)$ & $5.72(2.25-7.64)$ & $5.01(2.75-7.18)$ & 0.015 \\
\hline $\operatorname{HGB}(\mathrm{g} / \mathrm{dL})$ & $9.50(3.90-15.20)$ & $8.20(4.80-11.30)$ & 0.006 \\
\hline HCT (\%) & $28.30(13.40-43.30)$ & $23.90(12.50-32.30)$ & 0.003 \\
\hline RDW (\%) & $17.50(11.10-27.80)$ & $18.95(12.50-27.20)$ & 0.050 \\
\hline PDW (\%) & $7.60(5.50-12.20)$ & $8.35(5.90-10.30)$ & 0.024 \\
\hline Healthy piglets & $\mathrm{AA}, \mathrm{n}=119$ & $\mathrm{GA}, \mathrm{n}=14$ & \\
\hline $\mathrm{Fe}(\mathrm{mol} / \mathrm{L})$ & $11.64(3.58-51.22)$ & $9.85(5.91-14.15)$ & 0.044 \\
\hline WBC $\left(10^{9} / \mathrm{L}\right)$ & $15.26(6.51-22.85)$ & $12.92(8.56-20.03)$ & 0.006 \\
\hline \%LYM (\%) & $45.05(28.22-62.88)$ & $48.24(40.22-60.75)$ & 0.029 \\
\hline $\operatorname{GRA}\left(10^{9} / \mathrm{L}\right)$ & $6.70(2.40-12.70)$ & $5.25(2.60-8.20)$ & $<0.001$ \\
\hline$\%$ GRA (\%) & $44.57(24.59-64.73)$ & $38.42(29.61-52.93)$ & 0.011 \\
\hline MCV (fL) & $50.05(40.60-62.10)$ & $43.15(39.70-57.70)$ & 0.007 \\
\hline HCT (\%) & $29.80(21.40-43.40)$ & $28.80(20.10-32.30)$ & 0.049 \\
\hline $\mathrm{MCH}(\mathrm{pg})$ & $17.10(13.60-20.60)$ & $15.70(14.00-18.70)$ & 0.009 \\
\hline Anaemic piglets & $\mathrm{AA}, \mathrm{n}=45$ & $\mathrm{GA}, \mathrm{n}=15$ & \\
\hline MCV (fL) & $48.75(42.80-64.60)$ & $53.50(45.80-63.40)$ & 0.006 \\
\hline $\mathrm{MCH}(\mathrm{pg})$ & $17.30(14.10-21.80)$ & $18.50(15.00-20.90)$ & 0.021 \\
\hline Older piglets & $\mathrm{AA}, \mathrm{n}=190$ & $\mathrm{GA}, \mathrm{n}=9$ & \\
\hline \multirow[t]{2}{*}{ HDL-ch (mg/dL) } & $49.50(20.00-83.00)$ & $44.00(29.00-47.00)$ & 0.017 \\
\hline & $\mathrm{n}=172$ & $\mathrm{n}=9$ & \\
\hline WBC $\left(10^{9} / \mathrm{L}\right)$ & $19.98(8.44-39.03)$ & $23.90(18.46-28.97)$ & 0.045 \\
\hline \%LYM (\%) & $38.83(16.36-57.89)$ & $35.21(30.42-36.82)$ & 0.012 \\
\hline $\operatorname{GRA}\left(10^{9} / \mathrm{L}\right)$ & $10.50(4.10-24.30)$ & $12.70(11.10-17.40)$ & 0.015 \\
\hline$\%$ GRA (\%) & $51.43(32.21-77.71)$ & $56.96(49.79-60.85)$ & 0.007 \\
\hline $\mathrm{MCH}(\mathrm{pg})$ & $17.10(15.00-19.60)$ & $18.00(16.30-24.10)$ & 0.046 \\
\hline RDW (\%) & $16.65(10.60-22.10)$ & $13.50(11.00-17.30)$ & 0.025 \\
\hline
\end{tabular}




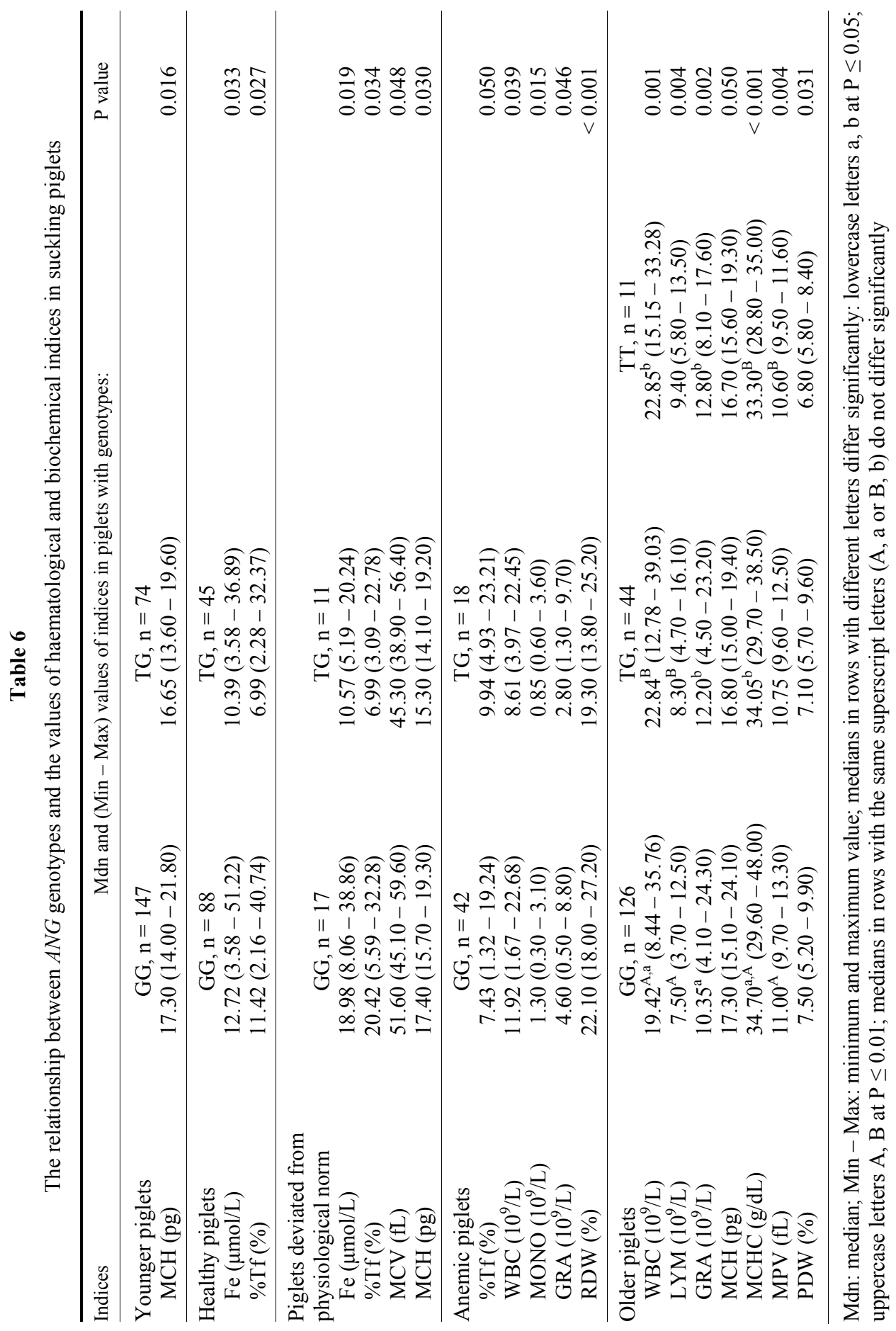




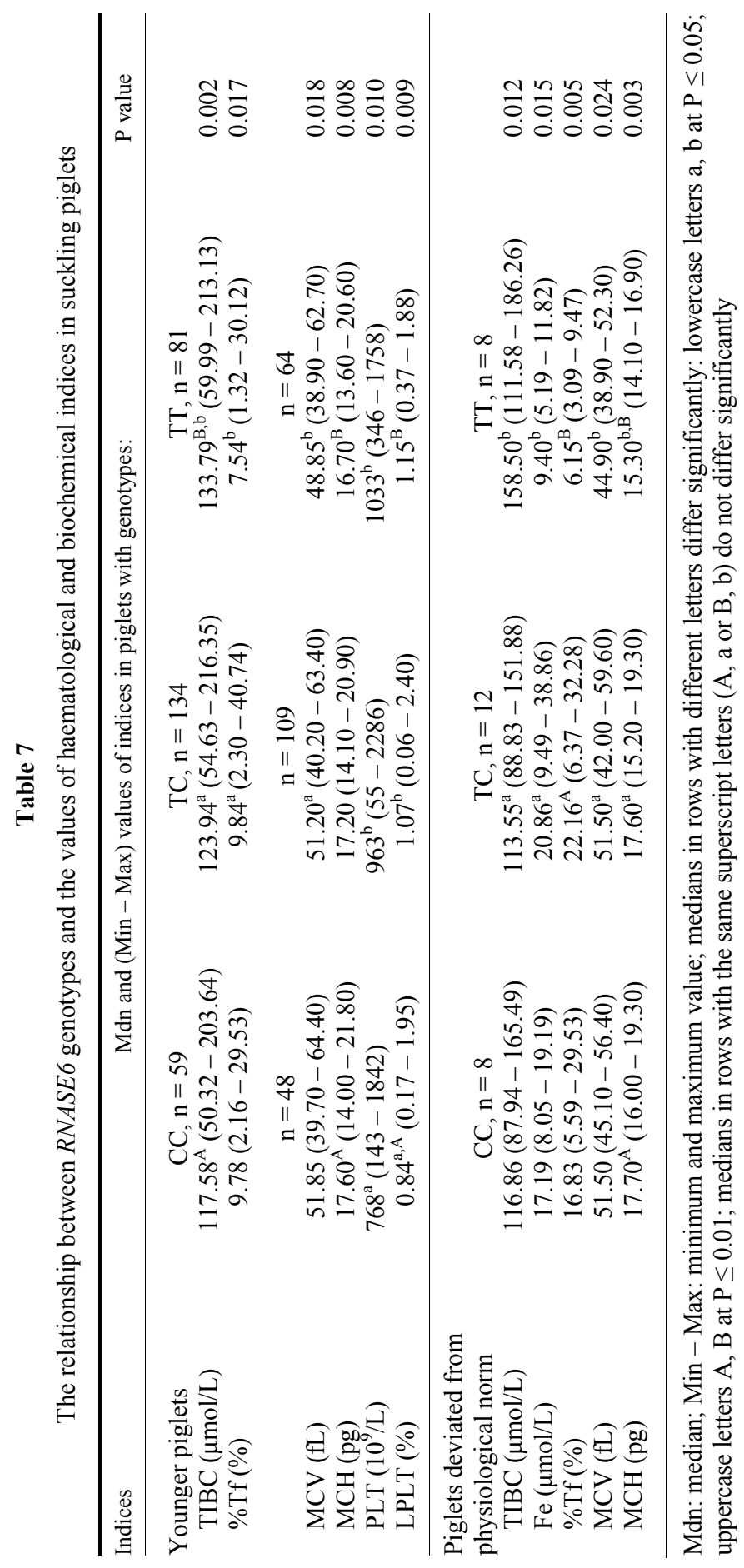




\section{Discussion}

In the present study RNASE1 gene polymorphism was revealed in AA and GA genotypes (Table 1). In contrast, Bai et al. (2009) observed the monomorphism of the RNASE1 gene in a Landrace pig population. Simultaneously, they noted quite different frequencies of $A N G$ genotypes GG, TG and TT (13.2\%, $40.1 \%$ and $46.7 \%$, respectively). Conversely, in our study piglets of GG genotype were the most common and those with TT occurred the least frequently (Table 1). Bai et al. (2009) reported that among RNASE6 genotypes the most frequent genotype was TT $(59 \%)$ while CC was the least frequent $(7.8 \%)$. This is inconsistent with our results which showed a similar frequency of the opposite homozygotes (Table 1).

The levels of iron status indicators in younger piglets (Table 2) exceeded the reference values determined by Egeli et al. (1998). As a consequence of anaemia in younger piglets, WBC counts as well as the number and percentage of their subpopulations also deviated from the reference norm (Duncan and Prasse, 1986; Quintero-Gutiérrez et al., 2008). The levels of blood indices reported in Table 2 indicated iron deficiency in some of the younger piglets, either in latent or clinically apparent form, while in others asymptomatic inflammation could occur that was included in further analysis. In contrast, the haematological and serum biochemical values obtained in older piglets much less frequently exceeded the physiological limits (Table 3).

As a result of RNASE1 (296 A/G) gene polymorphism younger GA piglets exhibited lower values of $\mathrm{WBC}$ and $\mathrm{RBC}$ indices than AA piglets, and healthy GA piglets also had a lower Fe compared to AA animals (Table 5). In contrast, in older GA piglets WBC indices including GRA and \%GRA as well as MCH were higher. In younger GA piglets such results can be explained by the higher incidence of iron deficiency anaemia (IDA) compared to AA individuals (Table 4). However, the effect of IDA on WBC was not clear and probably did not affect the total leukocyte count but could change the proportions of their components (Egeli et al., 1998). Anaemic GA piglets also had MCV and MCH values close to the physiological norm (Table 5). This was typical of normocytic anaemia, characterised by an excessive reduction in RBC count but normal RBC size and haemoglobin content (Brill and Baumgardner, 2000). Older piglets did not exhibit iron deficiency. Although the lower HDL-ch in GA than AA piglets suggested subclinical inflammation (Khovidhunkit et al., 2004), it was not accompanied by increased platelet indices (Yadav et al., 2010). The age-dependent effect of RNASE 1 gene mutation should be considered through the physiological processes occurring during the early postnatal period in piglets. Between 14 and 35 days of age, the very intense body weight gain and delayed development of the haematopoietic system promotes the development of physiological anaemia which, together with the disappearance of colostral antibodies, predisposes to infection by 
pathogens (Egeli et al., 1998). The acceleration of metabolism in growing piglets leads to oxidative stress intensified by the generation of superoxide anions $\mathrm{O}^{2-}$ from blood phagocytes as well as malondialdehyde, an indicator of lipid peroxidation due to the digestion of sow milk (Petrovič et al., 2009). The severity of oxidative stress is also enhanced by IDA (Nagababu et al., 2008). Therefore, the age and the levels of blood indices characteristic of iron deficiency in the younger piglets of this study confirmed the occurrence of oxidative stress. Moreover, the different $\mathrm{MCV}$ and $\mathrm{MCH}$ values of anaemic piglets suggesting the earlier elimination of red blood cells in the GA genotype further indicated the higher incidence of anaemia in this genotype than in AA. The shortened erythrocyte lifespan in the circulation might result from the oxidation of haemoglobin and RBC protein sulphhydryl groups (Pandolfi et al., 1995), iron deficiency causing heme loss, increased methaemoglobin levels, the generation of reactive oxygen species (ROS) (Nagababu et al., 2008) and the spontaneous endocytosis of extracellular pancreatic ribonuclease (Moenner et al., 1998). In cells, the cytotoxic activity of RNase 1 is limited by the ribonuclease inhibitor (RI/RNH1), the biochemical structure of which in swine makes it particularly sensitive to oxidative stress (Lomax et al., 2014). Thus, in erythrocytes the oxidation process leads to the undetectable loss of RI/RNH1 activity and the aging of RBC and their rapid uptake by macrophages. The higher incidence of anaemia in younger piglets with RNASE 1 GA genotype compared to AA may suggest a stronger mutationinduced destructive activity of RNase 1 on erythrocytes and the lack of control by its inhibitor which was inactivated by oxidative stress occurring during suckling period. In older GA piglets, owing to the lack of iron deficiency and the intensified oxidation processes the increased RNase 1 activity stimulated a defensive reactivity of this genotype, which was confirmed by the higher count and percentage of granulocytes in their blood.

The $A N G(149 \mathrm{G} / \mathrm{T})$ gene polymorphism reported by Bai et al. (2009) was associated with the lowest $\mathrm{MCV}$ and $\mathrm{MCH}$ in newborn TT piglets and the highest in GG animals. In older (32 days old) TT piglets a lower MCV was found than in the other genotypes. Similarly, in our study, an association between the T allele in homozygous and heterozygous piglets and the low MCH was noted, independently of their age and health status (Table 6). Additionally, in piglets deviating from the physiological norm and in older piglets low MCV and MCHC values were found, respectively (Table 6). Healthy TG piglets deviating from the physiological norm exhibited lower Fe and \%Tf than GG piglets (Table 6), which reflected different stages of iron deficiency in their organisms. Therefore, perhaps in younger piglets, iron deficiency might differentiate the reactions of genotypes to the limited oxygen availability in tissues, since it is known that hypoxia and oxidative stress occur in the early postnatal period (Petrovič et al., 2009). Hypoxia also induces the synthesis of angiogenin which protects motor neurons against hypoxic damage, but the missense mutations of its gene result in 
a loss of protein function (Pizzo et al., 2013; Sheng and Xu, 2016). Under conditions of oxidative stress, angiogenin has been shown to possess cytoprotective properties and be controlled by RI/RNH1 inhibitor susceptible to ROS (Pizzo et al., 2013). In oxidative stress, the cytoplasmic ANG-RNH1 complex dissociates because of inhibitor loss, and active angiogenin reprograms protein translation and enhances cell survival. Perhaps this cytoprotective effect of angiogenin could be of particular importance with regard to the WBC count found in anaemic GG piglets (Table 6). Although the lowest \%Tf and the highest RDW were unfavourable, a significant increase in WBC count including monocytes and granulocytes was observed in their blood compared to the heterozygotes.

Bai et al. (2009) reported the lowest MPV and LPLT in the blood of newborn TT piglets and the highest in GG homozygotes. However, our study showed the lowest values of MPV and PDW in older TT piglets compared to the TG and GG genotypes (Table 6). Perhaps the values of these parameters might be explained by the insignificantly elevated thrombocyte count in the blood of TT piglets due to its negative correlation with platelet size (Wasiluk, 2010). Intensified thrombocytopoiesis as a consequence of iron deficiency via erythropoietin or interleukin-6 stimulation (Wasiluk, 2010) could explain the lowest MCH and MCHC found in older TT piglets (Table 6). Moreover, in these piglets the WBC count including lymphocytes and granulocytes was higher than in GG animals and it slightly exceeded the reference values (Table 6). The WBC count indicated the acuteness of inflammation; however, its variation between the opposite homozygotes could be attributed to their differential immune reactivity, which was less expressed in GG homozygotes and stronger in TT homozygotes and heterozygotes. The highest MPV value found in the GG genotype was indicative of the most pronounced haemostatic activity of platelets, which are able to interact with bacteria before phagocytes during infections (Wasiluk, 2010) and can synthesise about 300 active substances including angiogenin (Whiteheart, 2011). Therefore, it is possible that MPV, together with the highest PDW value found in older GG piglets, was responsible for the maintenance of platelet-mediated host defence despite the decreased WBC count. However, the lower values of WBC indices and elevated erythrocyte and platelet parameters in older GG piglets may be due to the anti-inflammatory role of angiogenin, which has been recently explained by Lee et al. (2014). Angiogenin abolished TANK-binding kinase 1 activity in the translocation of NF- $\kappa \beta$ and inhibited the expression of proinflammatory interleukins (IL) IL-1 $\beta$, IL-6 and IL-8, but enhanced the expression of antiinflammatory cytokines IL-4 and IL-10.

The RNASE6 (389 C/T) gene polymorphism according to Bai et al. (2009) was associated with the lowest MCV and MCH in newborn TT piglets in comparison with the highest $\mathrm{MCV}$ and $\mathrm{MCH}$ in $\mathrm{CC}$ homozygotes. Piglets with $\mathrm{CC}$ genotype were also characterised by the highest percentage of neutrophils but in our study no association with the values of WBC indices was observed. Howev- 
er, this concerned only the younger piglets, among which the TT genotype was distinguished not only by the lowest MCV and MCH but also by the highest TIBC, the lowest \% Tf and the highest PLT and LPTL. TT piglets deviating from the physiological norm had the highest TIBC and the lowest Fe, \%Tf, MCV and $\mathrm{MCH}$. Therefore, the state of iron deficiency was the most apparent in younger TT piglets. The interpretation difficulty of the results obtained may lie in the still hypothetical role of RNase 6, but perhaps the findings can be explained by the coupling of the RNASE6 gene with other genes affecting the value of the indices studied.

\section{Acknowledgement} Fund.

This work was supported by the European Union within the European Social

\section{References}

Bai, X., Liang, Z., Zhao, S., Liu, X., Zhu, M., Wu, Z. and Yu, M. (2009): The porcine ANG, RNASE1 and RNASE6 genes: molecular cloning, polymorphism detection and the association with haematological parameters. Mol. Biol. Rep. 36, 2405-2411.

Brill, J. R. and Baumgardner, D. J. (2000): Normocytic anemia. Am. Fam. Physician. 62, 2255-2264.

Duncan, J. R. and Prasse, K. W. (1986): Veterinary Laboratory Medicine: Clinical Pathology. Second edition. Iowa State University Press, Ames. pp. 3-82.

Egeli, A. K., Framstad, T. and Morberg, H. (1998): Clinical biochemistry, haematology and body weight in piglets. Acta Vet. Scand. 39, 381-393.

Gansler, J., Preissner, K. T. and Fischer, S. (2013): Influence of proinflammatory stimuli on the expression of vascular ribonuclease 1 in endothelial cells. FASEB J. 28, 752-760.

Khovidhunkit, W., Kim, M. S., Memon, R. A., Shigenaga, J. K., Moser, A. H., Feingold, K. R. and Grunfeld, C. (2004): Effects of infection and inflammation on lipid and lipoprotein metabolism: mechanisms and consequences to the host. J. Lipid Res. 45, 1169-1196.

Koczera, P., Martin, L., Marx, G. and Schuerholz, T. (2016): The ribonuclease A superfamily in humans: Canonical RNases as the buttress of innate immunity. Int. J. Mol. Sci. 17, 1278-1294.

Lee, S. H., Kim, K. W., Min, K. M., Kim, K. W., Chang, S. I. and Kim, J. C. (2014): Angiogenin reduces immune inflammation via inhibition of TANK-binding kinase 1 expression in human corneal fibroblast cells. Mediators Inflamm. doi:10.1155/2014/861435.

Lomax, J. E., Bianchetti, C. M., Chang, A., Phillips, G. N. Jr, Fox, B. G. and Raines, R. T. (2014): Functional evolution of ribonuclease inhibitor: insights from birds and reptiles. J. Mol. Biol. 426, 3041-3056.

Moenner, M., Vosoghi, M., Ryazantsev, S. and Glitz, D. G. (1998): Ribonuclease inhibitor protein of human erythrocytes: characterization, loss of activity in response to oxidative stress, and association with Heinz bodies. Blood Cells Mol. Dis. 24, 149-164.

Nagababu, E., Gulyani, S., Earley, C. J., Cutler, R. G., Mattson, M. P. and Rifkind, J. M. (2008): Iron-deficiency anaemia enhances red blood cell oxidative stress. Free Radic. Res. 42, 824-829.

Pandolfi, P. P., Sonati, F., Rivi, R., Mason, P., Grosveld, F. and Luzzatto, L. (1995): Targeted disruption of the housekeeping gene encoding glucose 6-phosphate dehydrogenase (G6PD): G6PD is dispensable for pentose synthesis but essential for defense against oxidative stress. EMBO J. 14, 5209-5215. 
Petrovič, V., Novotný, J., Hisira, V., Link, R., Leng, L. and Kováč, G. (2009): The impact of suckling and post-weaning period on blood chemistry of piglets. Acta Vet. Brno 78, 365-371.

Pizzo, E., Sarcinelli, C., Sheng, J., Fusco, S., Formiggini, F., Netti, P., Yu, W., D’Alessio, G. and $\mathrm{Hu}, \mathrm{G}$. F. (2013): Ribonuclease/angiogenin inhibitor 1 regulates stress-induced subcellular localization of angiogenin to control growth and survival. J. Cell Sci. 126, 4308-4319.

Pulido, D., Arranz-Trullén, J., Prats-Ejarque, G., Velázquez, D., Torrent, M., Moussaoui, M. and Boix, E. (2016): Insights into the antimicrobial mechanism of action of human RNase6: Structural determinants for bacterial cell agglutination and membrane permeation. Int. J. Mol. Sci. 17, 552-571.

Quintero-Gutiérrez, A. G., González-Rosendo, G., Sánchez-Muñoz, J., Polo-Pozo, J. and RodríguezJerez, J. J. (2008): Bioavailability of heme iron in biscuit filling using piglets as an animal model for humans. Int. J. Biol. Sci. 4, 58-62.

Sheng, J. and $\mathrm{Xu}, \mathrm{Z}$. (2016): Three decades of research on angiogenin: a review and perspective. Acta Biochim. Biophys. Sin. 48, 399-410.

Tammen, I., Schulze, O., Chavez-Moreno, J., Waberski, D., Simon, D. and Harlizius, B. (1999): Inheritance and genetic mapping of the Campus syndrome (CPS): a high-frequency tremor disease in pigs. J. Hered. 90, 472-476.

Wasiluk, A. (2010): Thrombocytopenia - crucial clinical question in neonatology [in Polish]. Perinatol. Neonatol. Ginekol. 3, 5-9.

Whiteheart, S. W. (2011): Platelet granules: surprise packages. Blood 118, 1190-1191.

Yadav, D., Chandra, J., Sharma, S. and Singh, V. (2010): Clinicohematological study of thrombocytosis. Indian J. Pediatr. 77, 643-647. 